\title{
STIGMA, ANXIETY, RELIGIOSITY, AND ECONOMIC ON COVID-19 PREVENTIVE EFFORTS
}

\author{
Cucu Herawati ${ }^{1 *}$, Awis Hamid Dani ${ }^{1}$, Herlinawati ${ }^{1}$, Syaeful Bakhri ${ }^{2}$, Lilis Banowati, ${ }^{1}$ Nuniek Tri Wahyuni ${ }^{1}$ and \\ R. Nur Abdurakhman ${ }^{1}$
}

${ }^{1}$ Institute of Health Science of Cirebon, Cirebon, Indonesia

${ }^{2}$ Faculty of Sharia and Islamic Economics IAIN Syekh Nurjati of Cirebon, Cirebon, Indonesia

*Corresponding author: Cucu Herawati

Email: cucueherawatie@gmail.com

\begin{abstract}
Covid-19 can cause problems regarding physical, psychological, and socioeconomic health. It is due to the disease characteristics that are easily transmitted and can lead to death. Thus, strict measures are needed to reduce the spread of the disease, in this case, called preventive efforts. This study aims to determine the effect of stigma, anxiety, level of religiosity, and economic condition on Covid-19 preventive efforts. A cross-sectional design, data collection method using online survey with non-probability snowball sampling. The total sample of 451 students consisted of students in the field of health (the College of Health Sciences) and the field of religion (the State Islamic Institute). Analysis of the data in this study used a logistic regression test. There was an effect of stigma ( $P$ value $=0.000)$, level of anxiety $(P$ value $=0.000)$, and economic condition ( $P$ value $=0.001$ ) on Covid-19 preventive efforts, while there was no effect of the level of religiosity on Covid-19 preventive efforts. The most influential variable on Covid-19 preventive efforts was a stigma with an Odds Ratio (OR) of 2.256. If the stigma was low, there was no anxiety and the economic conditions were good, then there was a high probability of making preventive efforts.
\end{abstract}

Keywords: stigma; anxiety; economic; religiosity; preventive

\section{INTRODUCTION}

Infectious diseases including outbreaks, pandemics, and epidemics, can cause high morbidity and mortality and cause one-quarter to one-third of global death rates ${ }^{1}$. Covid-19 is included in infectious diseases that are very contagious, results in death, and the cure has not yet been found ${ }^{2,3}$. The continuous spread of the virus, strict isolation measures, and delays in schools, colleges, and universities have affected mental health ${ }^{4}$. According to WHO, Covid-19 emerged in December 2019, in the city of Wuhan, Hubei Province, China, and as a public health emergency of international concern on January $30,2020^{5}$. Globally up to $30^{\text {th }}$ July 2020 , there were $17,184,770$ confirmed Covid19 cases and 670,152 mortality cases $^{6}$. Covid-19 in Indonesia was first reported on $2^{\text {nd }}$ March 2020 with two cases $^{2}$. Data in Indonesia as of $28^{\text {th }}$ July 2020 showed that there were 104,432 confirmed cases, 62,133 recovered patients, and 4,975 deaths ${ }^{7}$.

Public health researches in Indonesia showed that patients who have confirmed positive with coronavirus faced stigma. Stigma exists because of a lack of appropriate knowledge related to Covid-19 disease $^{8}$. Inadequate knowledge, negative attitudes towards HIV transmission were found as factors that could influence the emergence of stigma and discrimination'. Stigma and discrimination tend to last in the long run, even after quarantine ends and the epidemic is under control ${ }^{10}$. Covid-19 spread have caused confusion, anxiety, and fear in the community, thereby affecting mental health and community behavior ${ }^{5}$. Fear and anxiety that accompany the Covid-19 pandemic can have adverse effects on mental health and have negative psychological and social effects ${ }^{11}$. Mental health problem expected to increase day after day during this epidemic. Psychiatric morbidity due to significant pandemic effects was been found to vary from depression, anxiety, panic attacks, psychosis, self-blame, and even suicide ${ }^{3}$.

Covid-19 outbreaks can be considered a spiritual crisis for people in some countries, their right to attend religious services has been severely restricted due to the need for infection control measures, including lockdown and quarantine ${ }^{12}$. Religion has a large role for individuals as a coping strategy. According to Argyle's opinion, religiosity helps individuals maintain psychological health when they are faced with problems. Religiosity can help in overcoming unpleasant events, and potentially instill good behaviour ${ }^{13}$. The world is hit by the burden of Covid-19 which has caused an economic ${ }^{14}$. The consequences of infectious diseases can trigger negative economic effects, which could potentially hamper economic recovery ${ }^{15}$. Public health can affect national resilience and global economic stability ${ }^{16}$. Social restrictions, self-isolation, and travel restrictions caused a decrease in the number of workers in all economic sectors and caused many people to lose their jobs. Schools are closed and demand for commodities and manufacturing products has decreased $^{17}$.

Social stigma is a mind-disturbing fear which further affects the health of the person. Many factors influence it, including religion which plays a significant role in increasing social stigma ${ }^{18}$. It is difficult to predict the long-term physical and mental health consequences of Covid-19. However, an economic crisis is very likely to occur which can worsen mental and emotional health problems ${ }^{19}$. Communities face several challenges during the pandemic period. Lack of awareness leads to ignorance, and this can affect readiness to deal with this pandemic especially prevention efforts. There is a lack of studies that evaluated mental health problems during this pandemic ${ }^{5}$. Based on the various problems mentioned regarding the impact 
of the Covid-19 pandemic, this study aims to determine the effect of stigma, level of anxiety, level of religiosity, and economic condition on Covid-19 preventive efforts among college students.

\section{METHODS}

This type of research is a cross-sectional study with a total sample size of 451 respondents consisting of students in the field of health studies and religious studies in West Java, Indonesia. The inclusion criteria in this study were physically and mentally healthy, willing to be a respondent, and residing in West Java, while the exclusion criteria were $>30$ years old, currently suffering from Covid-19, and students outside the fields of health and religious studies. Collecting data using online surveys via google form with a non-probability snowball sampling technique, namely a sampling technique from a population whose members are not clear and the number is uncertain ${ }^{2021}$. The variables in this study were the level of anxiety, stigma, religiosity, economic conditions, and the prevention of Covid19. The questionnaire to assess the level of anxiety used the HARS (Hamilton Anxiety Rating Scale) questionnaire which consisted of 14 question items. Meanwhile, the questionnaire to measure stigma consisted of 7 question items, religiosity as many as 8 question items, economic conditions as many as 8 question items, and prevention of Covid-19 as many as 10 question items, which were adopted from various previous studies $22,23,24,25,26$, so the validity and reliability were tested first before the study. Data analysis used univariate, bivariate, and logistic regression analysis ${ }^{27}$. This study has fulfilled four ethical principles of scientific research (respect for human dignity, respect for privacy and confidentiality, respect for justice and inclusiveness, and balancing must and benefits) which are registered with the Ethics Commission. Health Research Ethical Committee Health Research RSD Gunung Jati City Cirebon, with Ethical Clearance number: 041 / LAIKETIK / KEPKRSGJ / VIII / 2020.

\section{RESULTS}

Table 1: Characteristics of Study Subjects

\begin{tabular}{|c|c|c|c|c|}
\hline Characteristic & $\mathrm{n} \%$ & Mean \pm SD & Min - Max & Modus \\
\hline Age (years) & & $20.46 \pm 3.672$ & $17-49$ & \\
\hline Gender & & & & Female \\
\hline Male & $76(16.9)$ & & & \\
\hline Female & $375(83.1)$ & & & \\
\hline Field of Study & & & & Health \\
\hline Health & $361(80)$ & & & \\
\hline Religion & 90 (19.95) & & & \\
\hline Residence & & & & Cirebon \\
\hline Bandung & $11(2.4)$ & & & \\
\hline Cirebon & $389(86.3)$ & & & \\
\hline Garut & 21 (4.7) & & & \\
\hline Indramayu & $4(0.9)$ & & & \\
\hline Majalengka & $12(2.7)$ & & & \\
\hline Purwakarta & $14(3.1)$ & & & \\
\hline Total & $451(100)$ & & & \\
\hline
\end{tabular}

The average age of respondents was 20.46 years, The majority of respondents were female $83.1 \%$, the majority by respondents were students in the field of health of $80 \%$, and the majority of respondents came from Cirebon by $86.3 \%$. Table 2 showed that the majority of respondents experienced high stigma $61.6 \%$, no anxiety $67.2 \%$, a high level of religiosity $52.8 \%$, a good economic condition $60.3 \%$, and performed high preventive efforts $63.9 \%$.

The results showed that respondents who had a high stigma made high preventive efforts by $55.6 \%$ and a p-value of 0.000 , then it can be concluded that there was a relationship between stigma and Covid19 preventive efforts. The majority of respondents who experienced mild anxiety $86.1 \%$ made high preventive efforts and a $p$-value of 0.000 , then it can be concluded that there was a relationship between anxiety and Covid-19 preventive efforts.
The majority of respondents with low religiosity $59.6 \%$ made a high preventive effort, as well as the majority of respondents with a high level of religiosity $67.6 \%$ made high preventive efforts and a p-value of 0.094 , then it can be concluded that there was no relationship between the level of religiosity and COVID-19 preventive efforts. The majority of respondents with good economic condition $70.2 \%$ made high preventive efforts and a p-value of 0.001 , then it can be concluded that there was a relationship between the economic condition and COVID-19 preventive efforts.

The most dominant influential variable on Covid-19 preventive efforts was the stigma with an Odds Ratio (OR) of 2.256. It meant that individuals who experienced a high stigma had a risk of 2 times to make a low preventive effort compared to individuals who experienced a low stigma. 
Table 2: Frequency Distribution of Stigma, Level of Anxiety, Level of Religiosity, Economic Condition, and Covid-19 Preventive Efforts

\begin{tabular}{lll}
\hline Variable & Frequency & Percentage (\%) \\
\hline Stigma & 173 & 38.4 \\
Low & 278 & 61.6 \\
High & & \\
Level of Anxiety & 303 & 67.2 \\
No Anxiety & 36 & 8.0 \\
Mild Anxiety & 88 & 19.0 \\
Moderate Anxiety & 24 & 5.3 \\
Severe Anxiety & & \\
Level of Religiosity & 213 & 47.2 \\
Low & 238 & 52.8 \\
High & & \\
Economic Condition & 178 & 39.7 \\
Not Good & 272 & 60.3 \\
Good & & \\
Preventive Efforts & 163 & 36.1 \\
Low & 288 & 63.9 \\
High & 451 & 100 \\
\hline Total & & \\
\hline
\end{tabular}

Tabel 3: Effect of Stigma, Level of Anxiety, Level of Religiosity, Economic Condition on Covid-19 Preventive Efforts

\begin{tabular}{|c|c|c|c|c|c|c|c|}
\hline \multirow{3}{*}{ Variable } & \multicolumn{7}{|c|}{ Covid-19 Preventive Efforts } \\
\hline & \multicolumn{2}{|l|}{ Low } & \multicolumn{2}{|c|}{ High } & \multicolumn{2}{|c|}{ Total } & \multirow[t]{2}{*}{ P-value } \\
\hline & $\mathrm{n}$ & $\%$ & $\mathbf{n}$ & $\%$ & $\mathbf{n}$ & $\%$ & \\
\hline \multicolumn{8}{|l|}{ Stigma } \\
\hline Low & 40 & 23.1 & 133 & 76.9 & 173 & 100 & \multirow{2}{*}{0.000} \\
\hline High & 123 & 44.2 & 155 & 55.8 & 278 & 100 & \\
\hline Level of Anxiety & & & & & & & \multirow[t]{5}{*}{0.013} \\
\hline No Anxiety & 92 & 30.4 & 211 & 69.6 & 303 & 100 & \\
\hline Mild Anxiety & 5 & 13.9 & 31 & 86.1 & 36 & 100 & \\
\hline \multirow{2}{*}{$\begin{array}{l}\text { Moderate Anxiety } \\
\text { Severe Anxiety }\end{array}$} & 49 & 55.7 & 39 & 44.3 & 88 & 100 & \\
\hline & 17 & 70.8 & 7 & 29.2 & 24 & 100 & \\
\hline \multicolumn{7}{|l|}{ Level of Religiosity } & \multirow[t]{3}{*}{0.174} \\
\hline \multirow{2}{*}{$\begin{array}{l}\text { Low } \\
\text { High }\end{array}$} & 86 & 40.4 & 127 & 59.6 & 213 & 100 & \\
\hline & 77 & 32.4 & 161 & 67.6 & 238 & 100 & \\
\hline Economic Condition & & & & & & & \multirow[t]{3}{*}{0.031} \\
\hline Not Good & 82 & 45.8 & 97 & 54.2 & 179 & 100 & \\
\hline Good & 81 & 29.8 & 191 & 70.2 & 272 & 100 & \\
\hline
\end{tabular}

Table 4: Results of Logistic Regression Modeling

\begin{tabular}{rlllll}
\hline Variable & & B & P-value & OR & 95\% Cl \\
\hline 1. & Stigma & 0.814 & 0.000 & 2.256 & $1.456-3.497$ \\
2. & Anxiety & 0.572 & 0.008 & 1.772 & $1.164-2.698$ \\
3. Economic & 0.457 & 0.030 & 1.579 & $1.046-2.382$ \\
& Condition & & & & \\
\hline
\end{tabular}

\section{DISCUSSION}

Effect of Stigma on COVID-19 Preventive Efforts Based on the result of the study there was a relationship between stigma with Covid-19 preventive efforts. The resulting study is in line with some previous studies which stated that stigma encouraged people to hide diseases, prevented people from seeking immediate health care, and prevented the adoption of healthy behavior ${ }^{28}$. Stigma and discrimination had an impact on preventive efforts, and caused a decrease in the zest for the life of PLWHA ${ }^{29}$.

Stigma related to Covid-19 can endanger public health efforts related to pandemic management and increase distrust towards the public health system ${ }^{18}$. The result of this study showed that the 
high or low stigma among students was a factor that affected Covid-19 preventive efforts, such as using hand sanitizers, washing wearing masks when leaving the house, getting enough rest, exercising regularly every day, and eating nutritious food.

The stigma of PLWHA was shown by cynicism, excessive fear, and it had a great impact on HIV/AIDS prevention and control programs. People who had enough knowledge tended to have no fear and did not give a stigma against PLWHA ${ }^{9}$. Many factors are known to accelerate the social stigma of society, including false media, and information that is missed also increases social stigma in society ${ }^{8}$.

\section{Effect of the Level of Anxiety on COVID-19 Preventive Efforts}

The study result showed that there was a relationship between the level of anxiety and Covid19 preventive efforts wherein the majority of respondents did not experience anxiety by $67.2 \%$, had mild anxiety $(8.0 \%)$ and moderate anxiety $(19,0 \%)$. The study results are in line with previous studies such as a study conducted in China which showed that of 7143 students, around three third of them $(75.1 \%)$ did not experience any anxiety symptoms, $21.3 \%$ experienced mild anxiety, $2.7 \%$ experienced moderate anxiety and $0.9 \%$ experienced severe anxiety ${ }^{4}$. A relationship between the level of anxiety and smoking behavior among adolescents ${ }^{30}$. The result of this study showed that the majority of respondents did not experience anxiety by $67.2 \%$, because the majority of respondents were health students who had a fairly good knowledge of Covid-19 compared to nonhealth students.

Anxiety describes a state of concern, the uncertainty that is sometimes accompanied by a variety of physical complaints ${ }^{31}$. When anxiety occurs in the community, this can increase the behavior of prevention efforts, limitations in daily activities, and behavior avoidance which causes limited socialization. This can affect mental health $^{32}$. The recommendation to stay at home has caused changes in daily life which then increased the level of anxiety experienced ${ }^{33}$.

The development of fear that results in erratic behavior in a community amid an epidemic of infection is an unusual phenomenon because anyone of any sex and socio-demographic status can be infected. This is especially due to the characteristics of Covid-19 when the disease is widely spread, and currently, there is no definitive treatment. Behaviors such as frequent use of sanitizers, hand washing, and masks show increasing concern for preventive measures to avoid Covid-19 infection. Health behavior, in this case, Covid-19 preventive efforts are made to reduce anxiety. Thus, anxiety has a contribution to preventive efforts.

Anxiety is triggered by something unknown and arises before there is a new experience, which threatens one's identity and self-esteem ${ }^{34}$. Ignorance of the novelty of Covid-19, its transmission, and high mortality rates cause concern $^{32}$. In this situation, it is considered that online mental health consultations are better ${ }^{5}$.

\section{Effect of the Level of Religiosity on COVID-19 Preventive Efforts}

The results of this study showed that the majority of respondents who had a low level of religiosity made high preventive efforts, as well as the majority of respondents who had a high level of religiosity, made high preventive efforts. Then there was no relationship between the level of religiosity and Covid-19 preventive efforts. It is due to possibilities including the respondent were still students, where the task of adolescent growth and development is more towards groups, not on the activities of religiosity. The results of this study are in line with previous research which stated that students of the Faculty of Pharmacy, UIN Malang performed the same religious rituals as before the pandemic ${ }^{35}$.

Religiosity is defined as the extent of knowledge, belief, the practice of worship, rules, and appreciation of the religion one adopts in daily life $^{36}$. Religion is a system of several aspects, known as religious awareness and religious experience ${ }^{37}$. Behavioral indicators are realized if the community can understand and live the teachings of their religion because religious teachings are in harmony with human life and provide maximum rules and guidance to all people in living life in the world ${ }^{38}$. One's religious beliefs can oversee all of his or her actions, words, even thoughts. When someone is interested in something fun, then the faith will consider and act whether it is permissible or not to $\mathrm{do}^{39}$.

\section{Effect of Economic Condition and COVID-19 Preventive Efforts}

The result of this study showed that there was a relationship between the economic condition and Covid-19 preventive efforts. The result is in line with several previous studies which stated that the economic crisis resulting from a pandemic of disease could cause changes in human behavior that may decrease immunity ${ }^{40}$. Regarding changes in income, no respondent experienced an increase. It tended to be stable by $62.9 \%$ and $37.1 \%$ of respondents experienced a decrease in income ${ }^{41}$.

Economics is one of the important factors in human life. the economic condition can provide opportunities for humans to meet their daily needs such as food, drinks, clothing, shelter, etc ${ }^{42}$. Lower living standards during periods of economic stress can lead to poorer nutrition, which further potentially reducing immunity due to higher stress levels. The consequences of infectious diseases can trigger negative economic effects, which could potentially hamper economic recovery ${ }^{43}$. Covid-19 had a significant impact on the decline in productivity of the community, especially workers or employees which had implications for the health, economic, education, and social sectors are given there were some jobs or professions that could not be done at home ${ }^{41}$.

\section{The Most Influential Variable on COVID-19 Preventive Efforts was Stigma}

The results of this study found that the most dominant influential variable on Covid-19 preventive efforts was the stigma variable with OR of 2.256. It meant that individuals who experienced a high stigma had a risk of 2 times to make a low preventive effort compared to individuals who experienced a low stigma. The results of this study are in line with the results of previous studies which stated that stigma and discrimination against people with Covid-19 had an impact on preventive efforts. Stigma is the biggest obstacle to preventing 
HIV transmission and treatment. The emergence of stigma in the community is also one of the obstacles faced in the prevention of HIV/AIDS ${ }^{44}$. Stigma was found to prevent people from adopting healthy behaviors $^{2}$. In this study, it is shown in the behavior of preventive efforts towards Covid-19.

The tendency to experience psychological distress was evidenced to be influenced by various social and cultural factors, one of which is the degree of stigma $^{45}$. People tend to have stereotypes with labels, for example, certain views towards a person with Covid-19 is highly contagious. When stereotypes are attached to labels, people tend to no longer see the real person, but only stereotypes. The community then tends to separate themselves. negative behavior or discrimination is at the other end of the spectrum. The results of this study showed that stigma among students was the most dominant influencing factor on the seriousness and steps in Covid-19 prevention efforts. If stigma is low then people will show increased concern for clean living healthy behaviors to avoid Covid-19 infection through Covid-19 preventive efforts.

\section{CONCLUSIONS}

There was an effect of stigma, level of anxiety, and economic condition on Covid-19 preventive efforts, while there was no effect of the level of religiosity on Covid-19 preventive efforts. The most influential variable in Covid-19 preventive efforts was a stigma. Universities should work together across sectors with the Department of Health to increase student knowledge regarding Covid-19 in an integrated and continuous manner. Furthermore, students should be wiser in responding to information related to Covid-19 presented in various media, so that stigma and the level of anxiety among students may decrease which eventually has an impact on increased Covid-19 preventive efforts.

\section{Conflict of interest}

The authors have no actual or potential conflict of interest.

\section{Acknowledgment}

This study was supported for College of Health Sciences of Cirebon.

\section{REFERENCES}

1. Verikios G, Sullivan M, Stojanovski P, et al. Assessing Regional Risks from Pandemic Influenza: A Scenario Analysis. World Econ 2016; 39:1225-1255.

2. Abdillah LA. Stigma terhadap Orang Positif.2020; 2.

3. Cyrus SH HO, Cornelia YI, Roger CM. Mental Health Strategies to Combat the Psychological Impact of COVID-19 Beyond Paranoia and Panic.2020;1-6.

4. Cao W, Fang Z, Hou G, et al. The psychological Impact of the COVID-19 Epidemic on College Students in China. Psychiatry Res 2020; 287: 112934.

5. Roy D, Tripathy S, Kar SK, et al. Study of Knowledge, Attitude, Anxiety \& Perceived
Mental Healthcare Need in Indian Population during COVID-19 Pandemic. Asian J. Psychiatr 2020; 51: 102083.

6. Worldometers.2020. Available at: https: / / www. worldometers.info/coronav irus/.

7. Kementrian Kesehatan RI. Peta Sebaran Gugus Tugas Percepatan Penanganan Covid-19. Available at: https: //covid19.go.id/peta-sebaran.

8. Naushad M. Effects of Social Stigma on the Sick People of COVID-2019 in the Community of the World.2020; doi:10.2139/ssrn. 3600579 .

9. Balfour L, Corace K, Tasca GA, et al. High HIV Knowledge Relates to Low Stigma in Pharmacists and University Health Science Students in Guyana, South America. Int J Infect Dis 2010; 14: e881-e887.

10. Ramaci T, Barattucci M, Ledda C, et al. Social Stigma during COVID-19 and its Impact on HCWs Outcomes Social Stigma during COVID-19 and its Impact on HCWs Outcomes. 2020; doi:10.3390/su12093834.

11. Yao H, Chen J, H Xu, et al. Rethinking Online Mental Health Services in China during the COVID-19 Epidemic. Asian J. Psychiatr 2020; 50:102015.

12. Quadri SA. COVID-19 and Religious Congregations: Implications for Spread of Novel Pathogens. Int J Infect Dis 2020; 96: 219-221.

13. Fitriani A. Peran Religiusitas dalam Meningkatkan Psychological Well Being.2016.

14. Sallam M, Dababseh D, Yasee A, et al. Conspiracy Beliefs are associated with Lower Knowledge and Higher Anxiety Levels Regarding COVID-19 among Students at the University of Jordan. 2020; 0-23.

15. Suhrcke M, Stuckler D, Suk JE, et al. The Impact of Economic Crises on Communicable Disease Transmission and Control: A systematic Review of The Evidence. PLoS One 6.2011.

16. Dwinantoaji H, Dw S. Human Security, Social Stigma, and Global Health the COVID-19 Pandemic in Indonesia.2020; 52: 72-79.

17. Nicola M, Alsafi Z, Sohrabi C, et al. Since January 2020 Elsevier has Created a COVID-19 Resource Centre with Free Information in English and Mandarin on the Novel Coronavirus COVID- 19.2020.

18. Budhwani H, Sun R. Creating COVID-19 Stigma by Referencing the Novel Coronavirus as the ' Chinese Virus.2020; 22: 1-7. 
19. Irfan M, Naeem F. Coping with COVID-19: Urgent Need for Building Resilience Through Cognitive Coping With COVID-19. 2020;

10-13.

doi:10.35845/kmuj.2020.20194.

20. Soekidjo N. Metodologi Penelitian.Rineka Cipta.2012.

21. Syofian Siregar. Metode Penelitian Kuantitatif.Kencana.2017.

22. Hawari D. Manajemen Stres Cemas dan Depresi (5th ed.).Fakultas Kedokteran Indonesia .2016.

23. Van Brakel WH, Voorend CGN, Angermeyer MV. Guidelines to reduce stigma. What is Health-Related Stigma, 2011; 22. Retrieved from http: / / www.ilep.org.uk/technicaladvice/stigma-guidelines/.

24. Putriani YH, Shofawati A.Pola Perilaku Konsumsi Islami Mahasiswa Muslim Fakultas Ekonomi dan Bisnis Universitas Airlangga Ditinjau Dari TIngkat Religiusitas. Jurnal Ekonomi Syariah Teori Dan Terapan, 2015; 2(7): 570. https: / /doi.org/10.20473/vol2iss20157pp 570-582

25. Iskandar A, Possumah BT, Aqbar K. Peran Ekonomi dan Keuangan Sosial Islam Saat Pandemi Covid-19. Jurnal Sosial \& Budaya Syar-i FSH UIN Syarif Hidayatullah. Jakarta 2020; Vol. 7 No. 7: 625-638.

26. Kementrian Kesehatan RI. Pedoman Pencegahan dan Pengendalian Coronavirus Desease (COVID-19).2020 .

27. Sutanto Priyo Hastono. Analisis Data.Rajagrafindo Persada.2017.

28. IFRC, Unicef W. Social Stigma associated with COVID-19 A Guide to Preventing and Addressing. 2020; 1-5.

29. Lubis L, Sarumpet SM, Ismayadi. Hubungan Stigma, Depresi dan Kelelahan Dengan Kualitas Hidup Pasien HIV / AIDS di Klinik Veteran Medan.2016; VII: 1-12.

30. Husna C, Jannah SR. Kecemasan dan Perilaku Merokok Pada Remaja. 2019; X: 32-36.

31. Daud I, Mauriefle A, Yanti ED. Hubungan Tingkat Kecemasan dengan Kejadian Asma pada Pasien Asma Bronkial di Wilayah Kerja Puskesmas Kuin Raya Banjarmasin.2017; 8: 219-229.

32. Banerjee D. The COVID-19 Outbreak: Crucial Role the Psychiatrists can Play. Asian J. Psychiatr 2020; 50: 102014.
33. Tull MT, Edmonds KA, Scamaldo KM, et al. Psychological Outcomes Associated with Stay-at-Home Orders and the Perceived Impact of COVID-19 on Daily Life. Psychiatry Res 2020; 289: 113098.

34. Sulistyowati DA. Hubungan Kecemasan dengan Strategi Koping pada Anggota Keluarga dengan Riwayat Perilaku Kekerasan di Wilayah Surakarta.2014.

35. Syahrir A, Rahem A, Prayoga A. Religiusitas Mahasiswa Farmasi UIN Malang Selama Pandemi Covid-19. 2020; 25-34.

36. Haryati TD. Kematangan Emosi, Religiusitas dan Perilaku Prososial Perawat Di Rumah Sakit.2013; 2: 162-172.

37. Subandi MA. Psikologi Agama dan Kesehatan Mental.pustaka pelajar. 2013.

38. Jaenudin U, Tahrir T. Studi Religiusitas, Budaya Sunda, dan Perilaku Moral pada Masyarakat Kabupaten Bandung. J. Psikol. Islam dan Budaya 2019; 2: 1-8.

39. Bintari N, Dantes P, Sulastri M. Korelasi Konsep Diri dan Sikap Religiusitas terhadap Kecenderungan Perilaku Menyimpang Dikalangan Siswa Pada Kelas Xi Sma Negeri 4 Singaraja Tahun Ajaran 2013/2014. Jurnal Bimbing dan Konseling Undiksha 2013; 2.

40. Stuckler D, Basu S, Suhrcke M. The health implications of financial crisis: A review of the evidence. Journal Ulster Med 2009; 78: $142-145$.

41. Gisela, Maria R, Nurwati DRN. Analisis Pengaruh Peningkatan Jumlah Masyarakat Terkonfirmasi Covid-19 terhadap Produktivitas Penduduk.2020.

42. Silpa Hanoatubun. Dampak Covid - 19 terhadap Perekonomian Indonesia. J. Educ. Psychol 2020; Couns. 2.

43. Smith RD, Keogh MR, Barnett TJ. The Economy Wide Impact of Pandemic Influenza on the UK: A Computable General Equilibrium Modelling Experiment. BMJ 2009; 1298.

44. Maman S, Alber L, Parker L, et al. A comparison of HIV Stigma and Discrimination in Five International Sites: The Influence of Care and Treatment Resources in High Prevalence Settings. Soc. Sci. Med 2009; 68: 2271-2278.

45. Nur W, Murtaqib. Identifikasi Status Psikologis sebagai Upaya Pengembangan Model Rehabilitasi Klien HIV/AIDS Berbasis Komunitas. Jurnal Nurseline 2016; 1: 110. 